\title{
Research on the Current Situation and Development Trend of China Cruise Tourism from 2017 to 2019
}

\author{
Chen Ping \\ School of Management, Shanghai University, Shanghai, China \\ Email: 839318519@qq.com
}

\begin{abstract}
In recent years, the cruise industry has become the most rapid development of modern tourism industry, known as "the gold industry on the waterway." This paper proposes corresponding development strategies by summarizing the development of China's cruise tourism in 2017-2019, especially the changes in China's cruise industry.
\end{abstract}

Keywords: Cruise, cruise home port, tourism, development trend

\section{Cruise Tour Overview}

\subsection{Cruise Overview}

In the past, cruise ships used to transport mail between intercontinental or long distances of water, usually entrusted to large passenger ships that sailed on fixed routes. Such large passenger ships were called cruise ships. Thanks to the progress of the world air transport industry, intercontinental routes and long-distance water voyages were replaced by aircraft, and cruise ships gradually withdrew from the postal market and became cruise ships with leisure travel ${ }^{[1]}$. Nowadays, people no longer distinguish between "cruise" and "cruise ship". The cruise ship referred to in this article is a large-scale sea-going vessel that can meet the needs of people for sightseeing and tourism ${ }^{[2]}$.

\subsection{The Significance of the Development of Cruise Tourism}

\subsubsection{Economic significance}

Cruise tourism as a new way of tourism has driven economic development. Its economic effects are mainly reflected in the huge consumption action ${ }^{[3]}$. The development of cruise tourism has brought unprecedented opportunities for the economic development of the cruise port's home port area, which has driven local consumption and promoted the growth of the local economy. The consumption level of the cruise tourism customer base is relatively high, which is more effective than the aborigines. The development of related industries, catering, accommodation, transportation, sightseeing, entertainment facilities, shopping places gathered around the port, resulting in a gathering economy.

\subsubsection{Social significance}

The development of tourism has greatly boosted social employment. Cruise tourism is currently in an accelerated development stage in China, and the demand for labor has increased dramatically. Cruises are docked, and coastal tourists can feel the exotic atmosphere when they disembark, which is of great significance for enhancing the international image of the port city ${ }^{[4]}$.

\section{Current Situation of China Cruise Tourism in 2017-2019}

\subsection{The Growth Rate of China's Cruise Market Is Temporarily Slowing Down, Which is} Conducive to Market Adjustment

According to the China Transportation Association's Cruise Yacht Branch (CCYIA) data, in 2017, China's 11 major cruise ports including Shanghai, Tianjin, Dalian, Qingdao, Zhoushan, Wenzhou, Xiamen, 
Guangzhou, Shenzhen, Haikou and Sanya received 1,181 cruise ships. It increased by $17 \%$ year-on-year. In terms of the number of cruise passengers, China's 11 major cruise ports received a total of 4.954 million inbound and outbound tourists, an increase of $18 \%$ year-on-year. Among them, the number of Chinese tourists entering and leaving China was 4,780,600, an increase of $11 \%$ year-on-year. 17.4 million people, a year-on-year decline of 37\%.In 2017, there were only four cruise ship homes in Shanghai, Tianjin, Guangzhou and Shenzhen with a total of more than 100 ships. The annual number of cruise ships with less than 50 ships was Sanya, Zhoushan, Dalian, Haikou and Yantai. The terminal is facing greater operational pressure.

\subsection{China's Home Port Cruises Enter the Fast Update Period}

In 2017, the number of domestic cruise ships operating in the Chinese market reached 18. Although there are adjustments to the fleet deployment of Princess Cruises, but because of the confidence in the development potential of the Chinese cruise market, international cruise companies have launched the world's latest luxury cruise ships in China ${ }^{[5]}$. The market provides Chinese tourists with world-famous cruise products and services to accelerate the cultivation of Chinese tourists' cruise culture.

In 2017, China's home port cruise company mainly consists of Royal Caribbean Cruises, Mediterranean Cruises, Costa Cruises, Princess Cruises, and Yunding Cruises. The new cruise companies are Novartis Cruises and Yinhai Cruises. The local cruise companies mainly have Tianhai Cruises and Bohai Sea. Three companies, including cruise ships and exquisite diamond cruises. The home port cruises are mainly mass-class cruise ships, covering Ocean Quantum, Ocean Zanli, Ocean Voyager, Ocean Mariner, Selina, Atlantic, Victoria, Lucky, Lyric, New Century, Diamond Brilliant, China Taishan, Sapphire Princess, Princess Shengshi, Virgo, Yunding Meng, Joy, luxury level cruise is the silver shadow, the total tonnage is $1,876,400$ gross tons, the average tonnage is 104,200 tons, the average standard The passenger capacity reached 2,580, and the average maximum passenger capacity reached 2,934.

Table1. Domestic cruise ship statistics of China's cruise market in 2018.

\begin{tabular}{|c|c|c|c|c|c|}
\hline $\begin{array}{l}2017 \text { Home port } \\
\text { Cruises }\end{array}$ & $\begin{array}{l}\text { China's } \\
\text { first flight }\end{array}$ & Change in 2018 & $\begin{array}{l}\text { Added in } \\
2018\end{array}$ & Added in 2019 & $\begin{array}{l}\text { Added in } \\
2020\end{array}$ \\
\hline Ocean quantum & 2015.6 .25 & Home port operation & Brilliant & Venice & Glory \\
\hline Marine praise & 2016.6.28 & Home port operation & Gemini & Marine spectral number & \multirow{17}{*}{$\begin{array}{c}\text { Other } \\
\text { undecided }\end{array}$} \\
\hline Ocean Voyager & 2012.6.19 & Home port operation & Aquarius star & & \\
\hline Marine sailor & 2013.6.18 & Farewell to China & \multirow{15}{*}{ World dream } & & \\
\hline Selena & 2015.4.24 & Home port operation & & & \\
\hline Atlantic & 2013.7.4 & Home port operation & & & \\
\hline Victoria & 2012.5.18 & Farewell to China & & & \\
\hline Lucky number & 2016.4 .24 & Home port operation & & & \\
\hline Lyrical number & 2016.5 .4 & Farewell to China & & & \\
\hline New Century & 2015.5.15 & Home port operation & & & \\
\hline Diamond Brilliant & 2016.3.18 & Home port operation & & & \\
\hline Zhonghua Taishan & 2014.8.16 & Home port operation & & & \\
\hline Sapphire Princess & 2014.5.21 & Farewell to China & & & \\
\hline Princess of the Prosperous & 2017.7.11 & Home port operation & & & \\
\hline Virgo & 2014.7 & Home port operation & & & \\
\hline Genting Dream & 2016.11.13 & Farewell to China & & & \\
\hline Joy number & 2017.6.28 & Home port operation & & & \\
\hline Silver shadow & 2017.3.5 & Farewell to China & & & \\
\hline
\end{tabular}

In 2018, China's home port cruise were 16 ships, including Ocean Quantum, Ocean Zanli, Ocean Voyager, Brilliant, Selina, Atlantic, Lucky, Virgo, Gemini, and Aquarius. No., New Century, Joy, Princess of the Prosperous, Diamond, China Taishan, World Dream. "Ocean Quantum" will be operated in Singapore in 2019. From November 2019 to April 2020, the Marina Bay will operate for 34 months and voyages for 6 
months, including 4 nights, 5 nights and a small number of 7 night voyages. The destinations are Kuala Lumpur, Phuket and Penang. The "Ocean Zanli" will leave the Tianjin home port from May to September 2019 to deploy the Alaska route in Seattle, USA, and this period is the "peak season" of the Chinese cruise market. The Ocean Voyager will return to Australia to operate the Sydney route from 2019 to 2020.

Information from the "Cruise Reference". On May 18, 2018, the MSC Mediterranean Cruises splendidly opened its first flight in China at the Wusongkou International Cruise Port in Shanghai, China. The Wusongkou International Cruise Port welcomed the 10 millionth entry and exit. On May 18, 2019, the first Venetian cruise ship, the Venetian, which was specially designed for the Chinese market, opened its first flight in China. On June 6, 2019, the first cruise ship of the Super Quantum series belonging to the Royal Caribbean Cruises -"Ocean Spectral Number" opened the first flight in Shanghai. The new generation of the future flagship "Glory" of the Mediterranean Cruise will be stationed in China's home port in the spring of 2020, setting a new benchmark for China's home port cruises.

Table 2. Domestic port cruises for the Chinese market from 2018 to 2020

\begin{tabular}{cccccc}
\hline & Cruise & $\begin{array}{c}\text { Tonnage } \\
(\mathbf{1 0 , 0 0 0} \text { tons })\end{array}$ & $\begin{array}{c}\text { Total } \\
\text { Cabin }\end{array}$ & $\begin{array}{c}\text { Passenger } \\
\text { Capacity }\end{array}$ & $\begin{array}{c}\text { China's } \\
\text { First Flight }\end{array}$ \\
\hline & Added in 2018 & & & & \\
\hline Mediterranean cruise & Brilliant & 13.79 & 1637 & 4363 & 2018.5 .18 \\
Star Cruises & Aquarius star & 5.13 & 756 & 1511 & - \\
Star Dream Cruise & Gemini & 5.07 & 765 & 1530 & - \\
\hline & World dream & 15.13 & 1686 & 3352 & 2017.11 .19 \\
\hline Costa Cruises & Added in 2019 & & & & \\
Royal caribbean & Venice & 13.55 & 2116 & 5260 & 2019.5 .18 \\
\hline & Marine spectral number & 16.8 & 2137 & 5622 & 2019.6 .6 \\
\hline Mediterranean cruise & Added in 2020 & & & & 2020 \\
\hline
\end{tabular}

Information from the "Cruise Reference"

\subsection{China's Cruise Port Facilities Construction Is Gradually Improved}

According to the planning and layout of the cruise port by the Ministry of Transport, by 2030, China will form two or three major cruise ship home ports, with the cruise ship originating port as the main component and the port pattern supplemented by the visiting port ${ }^{[6]}$. Among them, it is proposed that Dalian coastal development will focus on Dalian Port, Tianjin-Jinhai coast will be Tianjin Port as the originating port, Shandong Coast will be Qingdao Port and Yantai Port as the originating port, and the Yangtze River Delta and above will be the port of origin, and Ningbo Yizhoushan Port will be developed accordingly. The southeast coast uses Xiamen Port as the originating port. The Pearl River Delta has recently focused on the development of Shenzhen Port, correspondingly developing Guangzhou Port, and the southwest coast with Sanya Port as the originating port, correspondingly developing Haikou Port and Beihai Port.

There are currently 15 cruise ports in China, including 8 cruise terminals. At present, China's cruise professional terminals mainly cover Shanghai Wusongkou International Cruise Port, Tianjin International Cruise Home Port, Shanghai Port International Passenger Transport Center, Qingdao Cruise Home Port, Shenzhen China Merchants Shekou International Cruise Port, Sanya Phoenix Island International Cruise Port, Zhoushan Islands International Cruise Port, Xiamen. There are 8 international cruise centers, including Dalian Port, Guangzhou International Cruise Port, Wenzhou International Cruise Port, Fangchenggang Port, Yantai Port, Xiuying Port and Beihai Port, which will be transformed by the freight terminal. Dalian International Cruise Port, Guangzhou Nansha Cruise Port, Beihai International Cruise Port, Haikou Nanhai Mingzhu International Cruise Port, Xiamen International Cruise Port, and many other new professional cruise ports, Ningbo and Qinhuangdao plan to build an international cruise port, and most of them are based on the mother port. 


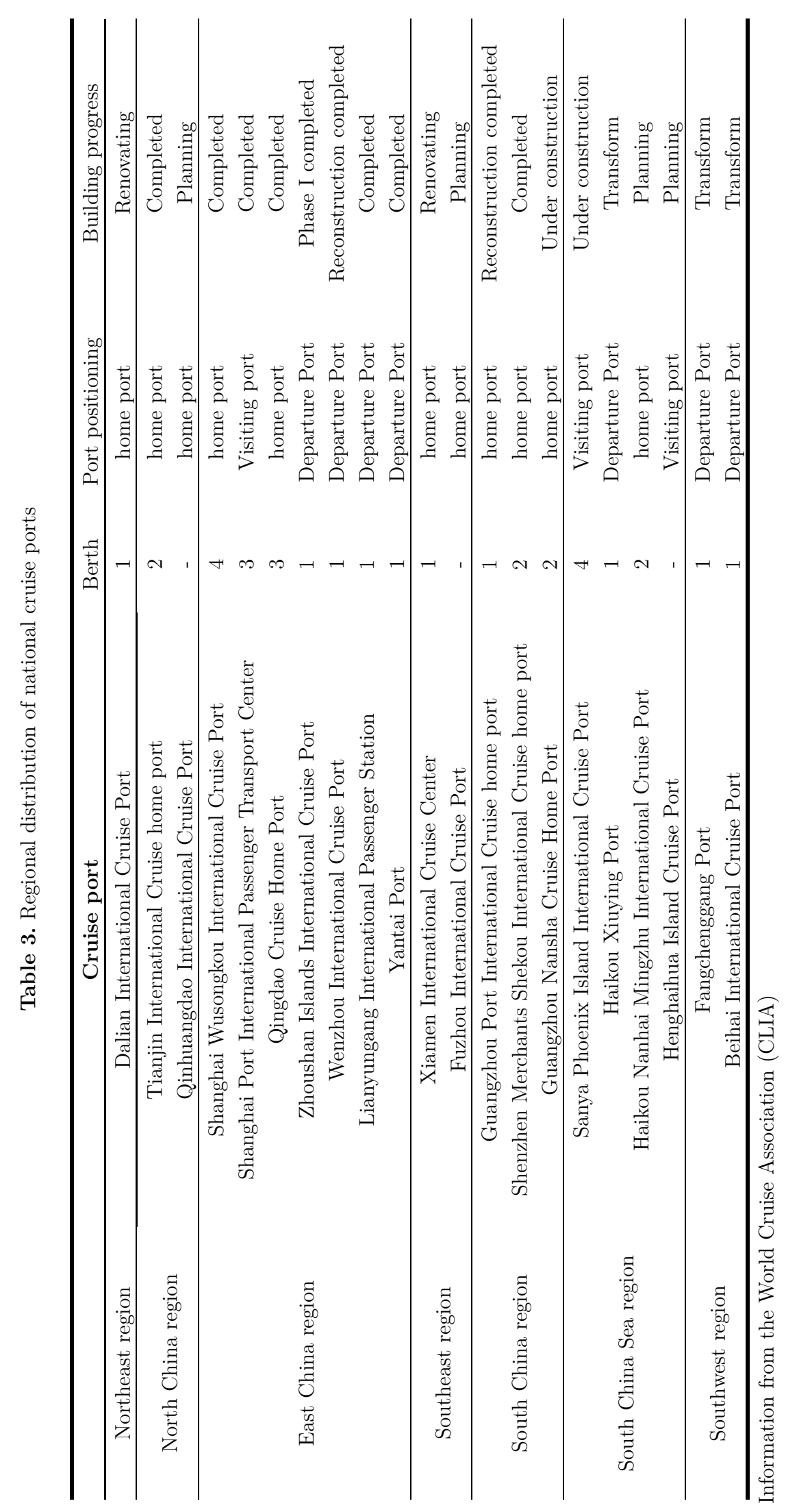




\subsection{Cruise Port Service Level Continues to Improve}

In recent years, in order to better promote the development of cruise ports and improve the service level of ports, many cruise ports have carried out the transformation of cruise ports, which has effectively enhanced the reception capacity of cruise ports. The construction of the Shanghai Wusongkou International Cruise Port project started on June 18, 2015. It is located on the upstream and downstream side of the existing construction of the cruise port. The total length of the newly built terminal in the upstream section is 380 meters, and the downstream section extends the shoreline of 446 meters. A terminal building, making the total passenger building area reach 79,000 square meters. The newly built hydraulic construction area is about 80,000 square meters. It will be fully completed in July 2018. After the completion, the Wusongkou International Cruise Port will form an overall berth size of two 150,000 gross tonnage and two 230,000 gross tonnage cruise ships.

At present, Guangzhou has accelerated the construction of cruise ports and adopted a layout of "main and auxiliary" cruise ports. Recently, a large cruise terminal was built mainly in Nansha. In the medium and long term, combined with the demand of the cruise tourism market, medium-sized cruise terminals were built in Huangpu and Panyu as appropriate. Guangzhou accelerated the construction of Nansha International Cruise Terminal. In November 2017, the Nansha Cruise Terminal project was fully started. In the first phase, a 225,000 gross tonnage, a 100,000 gross tonnage cruise berth and a 35,000 square meter terminal will be built. The annual pass capacity can reach 750,000 to 1 million person-times, and strive to be completed and put into production in 2020.

In recent years, Dalian Port has actively promoted the upgrading and upgrading of the hardware facilities of the cruise terminal. Previously, Dalian Port has completed the renovation of the 22-storey cruise terminal waiting room in the port area, which can meet the needs of 3,000 passengers for customs clearance, check-in, baggage check and waiting; in mid-April 2018, Dalian Port completed the cruise ship waiting room. Further optimization upgrades. In terms of berth upgrades, Dalian Port completed the renovation of the 150,000-ton cruise berth at the 10th to 11th berths in the port area at the end of last year, and the upgrading of the berths 8-9 was under intense construction. It is estimated that by 2020, Dalian Port will build an international cruise center with an area of 38,000 square meters, with a capacity of 10,000 passengers per day.

\subsection{Cruise Ports Continue to Promote Service Innovation}

In order to better enhance the port service experience and improve service levels, major cruise ports continue to promote service innovation. In April 2017, the "Cruise Express Customs Barcode" was commissioned at the Shanghai Wusongkou International Cruise Port. First implement the 144-hour transit visa-free and international cruise tour group's 15-day entry visa-free policy, which is the first to simplify the entry process for Chinese cruise passengers, reducing the inspection time from an average of 15 seconds to 3 seconds, reaching the world's leading level. Shanghai Wusongkou International Cruise Port actively promotes standardization construction. In November 2017, it successfully passed the certification of the Norwegian Classification Society and obtained the quality management system (QMS), environmental management system (EMS), and occupational health and safety management system (OHSAS) certification.

On December 29, 2017, the Shanghai International Cruise Service Center "High-speed Rail Cruises" Hongqiao Hub Service Station was put into trial operation. Shanghai fully implements the system of "online value ship, boarding pass (boarding permit) to board the ship", Royal Caribbean as the pilot unit of "Shanghai Cruise Ticket System (Pilot) Implementation Measures" was initially successful. Starting from March 31, 2018, the full implementation of the cruise ship ticket to the cruise port and the boarding of the cruise ship ticket model became the first cruise port in China to fully implement the cruise ticket system. The ticket system will further improve the guest boarding. In order to improve the punctuality rate of cruise ships, on August 31, 2017, the Yangtze River estuary deep-water channel super-wide ship actual ship rendezvous trial was implemented, and the large-scale cruise ship and heavy-duty large-scale container "two-way traffic" was implemented, effectively reducing the cruise delay rate. 


\subsection{Accelerating the Design and Manufacture of Domestic Cruise Ships}

The construction of domestic cruise ships is an important part and key content of the extension of China's domestic cruise industry chain. It can give play to China's advantages in shipbuilding on a global scale, build localized cruise ships, and build a local cruise fleet, which is important for mastering the world's cruise industry basis. The current world cruise construction market is monopolized by European cruise construction companies, mainly including the two major shipbuilding giants such as the German Meyer Shipyard and the Italian Fincantilini Group. Chinese local shipbuilding companies continue to promote the exploration and construction of domestic luxury cruise ships, support the continuous launch of relevant policies for cruise construction, promote the continuous promotion of industrial support funds for cruise design and construction, accelerate the acquisition of the "crown pearl of the shipbuilding industry", and break through the luxury cruise Construction technology.

\section{$3 \quad$ Analysis on the Development Trend of China's Cruise Industry in 2019}

\subsection{Further Adjustment and Optimization of China's Cruise Market}

In 2019, the number of cruise ships in China's cruise market reached 14 ships, two fewer than 16 ships in 2018. The number of cruise ships in the mother port decreased by $12.5 \%$ year-on-year. The number of cruise beds reached 40,342, a decrease of $5.2 \%$ from 2018. The capacity of the cruise market reached 1,940,800. People, down $13.5 \%$ from 2018. As the first cruise ship of the super-quantum series, "Ocean Spectral Number" will begin to sail from Shanghai in June 2019, and comprehensively upgrade the rooms, catering, entertainment and technology facilities on the basis of the "Ocean Quantum" cruise. It will become the largest and most expensive cruise ship in Asia, with a total tonnage of 168,000 gross tonnage, 2,137 rooms, 4,246 passengers, and a maximum capacity of 5,622 passengers, with 1,551 international crew members from all over the world. The new cruise ship "Venice", which is specially designed for the Chinese market, will be stationed in the mother port cruise market in China from 2019. The "Venice" will be built by the Italian Finkantini Group with a total tonnage of 135,500 Tons, the total number of cabins is 2,116 and the maximum passenger capacity is 5,260 visitors.

Table 4. 2019 China market home port cruises

\begin{tabular}{|c|c|c|c|c|c|}
\hline Cruise company & Cruise & $\begin{array}{c}\text { Number of } \\
\text { cruises }\end{array}$ & $\begin{array}{l}\text { Number } \\
\text { of beds }\end{array}$ & $\begin{array}{c}\text { Market } \\
\text { capacity }\end{array}$ & Market share \\
\hline \multirow{3}{*}{$\begin{array}{c}\text { Royal Caribbean } \\
\text { Cruises }\end{array}$} & Ocean quantum & \multirow{3}{*}{3} & \multirow{3}{*}{11400} & \multirow{3}{*}{530300} & $27.30 \%$ \\
\hline & Marine spectral number & & & & $32.00 \%$ \\
\hline & Ocean Voyager & & & & $9.50 \%$ \\
\hline \multirow{3}{*}{ Costa Cruises } & Selena & \multirow{3}{*}{3} & \multirow{3}{*}{9300} & \multirow{3}{*}{623100} & $4.10 \%$ \\
\hline & Atlantic & & & & $2.20 \%$ \\
\hline & Venice & & & & $12.30 \%$ \\
\hline Mediterranean cruise & Brilliant & 1 & 3300 & 184800 & $6.30 \%$ \\
\hline Princess Cruise & Princess of the Prosperous & 1 & 4600 & 79200 & $3.20 \%$ \\
\hline Novo Real Cruises & Joy number & 1 & 4200 & 42000 & $3.10 \%$ \\
\hline Star Dream Cruise & World dream & 1 & 3400 & 238000 & $27.30 \%$ \\
\hline \multirow{2}{*}{ Star Cruises } & Virgo & \multirow{2}{*}{2} & \multirow{2}{*}{3472} & \multirow{2}{*}{121520} & $32.00 \%$ \\
\hline & Aquarius star & & & & $9.50 \%$ \\
\hline Diamond cruise & Diamond Brilliant & 1 & 838 & 61174 & $4.10 \%$ \\
\hline Bohai Cruises & Zhonghua Taishan & 1 & 832 & 60736 & $2.20 \%$ \\
\hline total & & 14 & 40342 & 1940830 & $100 \%$ \\
\hline
\end{tabular}




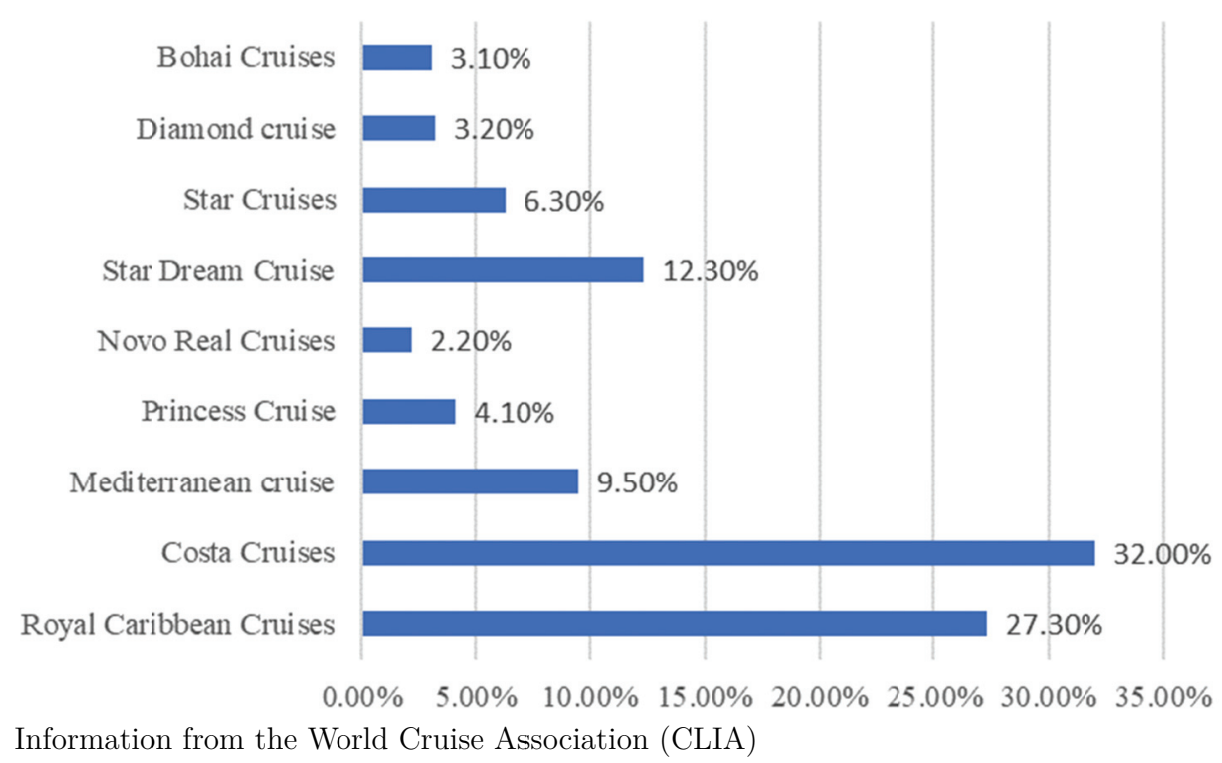

Figure 1. Market share of major cruise companies in the Chinese market in 2019

In terms of China's cruise market share in 2019, the Royal Caribbean Cruises market capacity reached 530,300 , with a market share of $27.3 \%$. The Costa Cruises market capacity reached 6i23,100, with a market share of $32.0 \%$, ranking first in China. The cruise market has a capacity of 238,000 passengers and a market share of $12.3 \%$, ranking third in China. In terms of Chinese cruise ships, with the Tianhai Cruise "New Century" gradually adjusted to the European market in September 2018, the Chinese cruise ship has only the diamond cruise "Glory" and the Bohai cruise "China Taishan", in 2019 Diamond Cruises provided capacity of 61,100 passengers, accounting for $3.2 \%$ of China's cruise market share. Bohai Cruises "China Taishan" provided capacity of 60,700 passengers, accounting for $3.1 \%$ of China's cruise market share, and only accounted for China's cruise market share. $6.3 \%$.

\subsection{The Quality of Cruise Products Has Become the Mainstream Trend of Market Development}

At present, China's social and economic development is in a good development trend. Consumption upgrading has become an important feature and trend of social development. People's demand for high-quality lifestyles and consumption patterns has become more vigorous, and the demand for high-quality tourism has become more prominent ${ }^{[7]}$. Traditional Traveling modes have been difficult to meet the needs of modern life. From the perspective of the entire tourism industry, China's tourism industry is no longer a single development business. Diversified and cross-border development has become the main theme of various formats. Personalized and quality products have become an important way for the tourism market to enhance competitiveness and expand market size. Tourism itself is the spiritual demand of people's life. The expansion of tourism market and the improvement of quality are the forms of social and economic development. At the same time, the development of tourism market has a direct relationship with the development of social economy. The transformation and upgrading of economic development also continuously promotes the continuity of tourism upgrade.

\subsection{The Extension of Each Section of the Cruise Industry Chain Will Gradually Accelerate}

China is in a period of rapid economic growth to high-quality growth, and it is a period of strategic opportunities for industrial transformation and upgrading. The cruise industry is a part of the tourism industry with rapid growth and high added value, including cruise design and construction, cruise operation, cruise port operation and related supporting industries and service industries. The combination with the industrial chain is effective in improving the economic benefits of the cruisie industry way. 


\subsection{The Reception Level of the National Cruise Port Will Be Further Improved}

In the construction of China's international cruise port, most of them are positioned as the international cruise ship home port, and actively carry out the business of the cruise port home port. The homogenization development mode of the cruise port is more serious. At present, most of the construction and planning of international cruise ports are self-planned by local governments and enterprises. They have not yet been considered nationally. A large number of cruise port idle problems are more serious and their profitability is poor. In the development of international cruise ports, the coordinated development of the cruise port and the visiting port should be realized, and the overall development of the cruise port should be further improved to avoid the blind construction of the cruise port, the idleness of the cruise port and the waste of port resources.

\section{Conclusion}

Overall, the growth rate of China's cruise market has slowed down briefly. China's home port cruises have entered a period of rapid renewal. China's cruise tourism is facing market adjustment, and the quality of cruise products has become the mainstream trend of market development. Under this situation, the cruise tourism marketing needs to accurately locate its target market and the cruise company should gradually cultivate its own sales team, to save the market, seize the market opportunity, and master the market leading power.

\section{References}

1. Sun Xiaodong, Feng Xuegang. China Cruise Tourism Industry: Research Status and Prospects[J]. Tourism Journal, $2012(02)$.

2. Shen Linlin, Luo Yongquan. Discussion on the problems and solutions of cruise tourism $[\mathrm{J}]$. Tourism Overview (the second half of the month), 2015 (03).

3. Liu Jun.Research on the development of China's cruise (tourism) home port from the perspective of regulation [D]. Fudan University, 2011.

4. Zhang Xiaojuan. Study on the economic effects of cruise tourism and its transmission mechanism [D]. Xiamen University, 2018.

5. Liuxing. Analysis of current status and development prospects of cruise tourism economic management [J]. Journal of Guangzhou University, 2017(03).

6. Zhang Yanqing Min Min, Ma Bo. Review of overseas cruise tourism market research [J]. Tourism Journal, 2017(02).

7. Zhang Yanqing Ma Bo, Liu Tao.Characteristics of the international cruise tourism market and China's outlook [J]. Tourism Forum, 2018 (04). 